\title{
Influence of Visual, Auditory, Kinesthetic Learning Style on the Ability of Troubleshooting E-Learning-Based Math
}

\author{
Rizky Ikhwan Permana ${ }^{1} \quad$ Zul Amry ${ }^{2} \quad$ Mulyono $^{3}$ \\ Medan State University, Jalan Willem Iskandar Pasar V, Medan, Indonesia
}

\begin{abstract}
This study aims to: Know the effect of VAK learning styles on students 'mathematical problem solving abilities, Know the contribution of each learning style to students' mathematical problem solving abilities, Know the effect of VAK learning styles on e-learning, and Know the contribution of each learning style to e-learning. This type of research is a quasi experiment. The population in this study were all grade VII students of SMP Negeri 1 Binjai and the sample in this study were 3 classes of 96 students. The results showed that there was influenceVAK learning style on students' mathematical problem solving abilitiesof Fcount $=2.746$ greater than Table $=2.70$; and there are contributions significant from each of them VAK learning style on students' mathematical problem solving abilitiesin SMP Negeri 1 Binjai that is overallby $8.2 \%$, visual learning styles by $8.1 \%$, auditory learning styles by $0.9 \%$, and kinesthetic learning styles by $2.1 \%$. Next there is influenceVAK learning style towards e-learning learningof Fcount $=2.783$ greater than Table $=2.70$; and there are contributionssignificant from each of them VAK learning style towards e-learning learningin SMP Negeri 1 Binjai that is overallby $8.3 \%$, visual learning styles by $6.4 \%$, auditory learning styles by $1.2 \%$, and kinesthetic learning styles by $5.2 \%$. Thus it can be concluded that there is an influence of VAK learning style on students' mathematical problem solving abilities based on e-learning in SMP Negeri 1 Binjai.
\end{abstract}

Keywords: VAK learning styles, students' mathematical problem solving abilities, e-learning learning

DOI: $10.7176 / \mathrm{JEP} / 11-18-20$

Publication date:June 30th 2020

\section{PRELIMINARY}

Education is a process of educating, which is a process in order to influence students to be able to adapt themselves as best as possible to their environment, so that it will cause changes in themselves. Thus, education is a priority factor that needs to be built and improved in quality (Sutikno, 2006).

Mathematics is very important to be taught to all students because its contribution is very broad and useful in all aspects of human life. But in reality, many people view mathematics as the most difficult field of study, from elementary school to tertiary level. As revealed by Abdurrahman (2012) that from various fields of study taught at school, mathematics is a field of study that is considered the most difficult by students, both those who have no learning difficulties and more so for students who have learning difficulties.

One aspect emphasized in the curriculum is improving students' problem solving abilities. Problem solving is part of a very important mathematics curriculum because in the learning process and its completion, students are allowed to gain experience using knowledge and skills that are already possessed to be applied to solving problems that are not routine. Cooney (Hudojo, 2015) said that teaching students to solve problems enables students to be more analytical in making decisions in life. But it is considered the most difficult part in learning it and for teachers in doing it. A problem usually contains a situation that encourages someone to solve it.

According to Amir (2013) states that each individual has differences between one another. These differences vary, ranging from physical differences, patterns of thinking and ways to respond or learn new things. In terms of learning, each individual has advantages and disadvantages in absorbing the lessons given. Therefore in the world of education various methods are known to be able to meet the demands of individual differences.

This is in accordance with the opinion of DePorter \& Hernacki (2016) that "The problem may be a mismatch between the student's learning style and the teacher's learning style". DePorter \& Reardon (2014) further explained that teachers tend to teach with their learning styles. However, not all students have the same learning style as the teacher. There are students who like the teacher teaching by writing everything on the board. There are also students who prefer the teacher to teach by delivering material orally, and there are those who directly describe the contents of the teacher's lectures in a form that they understand themselves. Student differences in managing the information above are influenced by learning styles. So students experience a mismatch between the learning styles of the teacher and the learning styles they have.

Based on the ability of the brain to absorb, manage and convey information, individual learning styles can be divided into 3 categories. The three categories are visual, auditory and kinesthetic learning styles which are characterized by certain behavioral traits. This categorization does not mean that each individual only has one characteristic of a particular learning style so that it does not have the characteristics of another learning style. This categorization is only a guideline that each individual has one of the most prominent characteristics so that 
if he gets an appropriate stimulus in learning it will make it easier to absorb the lesson. In other words, if the individual finds a learning method that is suitable with the characteristics of the way he learns, then he will quickly become "

This is also supported by the results of an interview with one of the mathematics studies teachers at SMP Negeri 1 Binjai saying that "Generally students have difficulty in learning mathematics when the questions given are not the same as the examples. If the problem varies or is different from the example given, students will find it difficult to work on the problem. Students are also less able to solve problems in the form of stories. Teachers generally deliver material using lecture and discussion methods without regard to the learning style trends of each student. Therefore, at the beginning of the learning experience, one of the steps of the teacher is to recognize one's learning style, namely visual, auditory, and kinesthetic learning styles.

The purpose of writing this article is to determine the effect between VAK learning styles (Visual, auditory, kinesthetic) towards students' mathematical problem solving abilities based on e-learning.

\section{RESEARCH METHODS}

This type of research used in this study is a quasi experimental method, namely research that aims to determine the effect of VAK learning styles (Visual, Auditory, Kinesthetic) on the ability to solve mathematical problem solving based on e-learning.

This study involved three sample classes that applied VAK learning styles with one variable linear equation material. To measure the ability to solve mathematical problems obtained from the application of these treatments, students are given a final test. The research design used in this study is the Postest Control Group Design. Posttest is used to measure the ability to solve mathematical problems after treatment. The research design carried out in this experimental study is presented as follows.

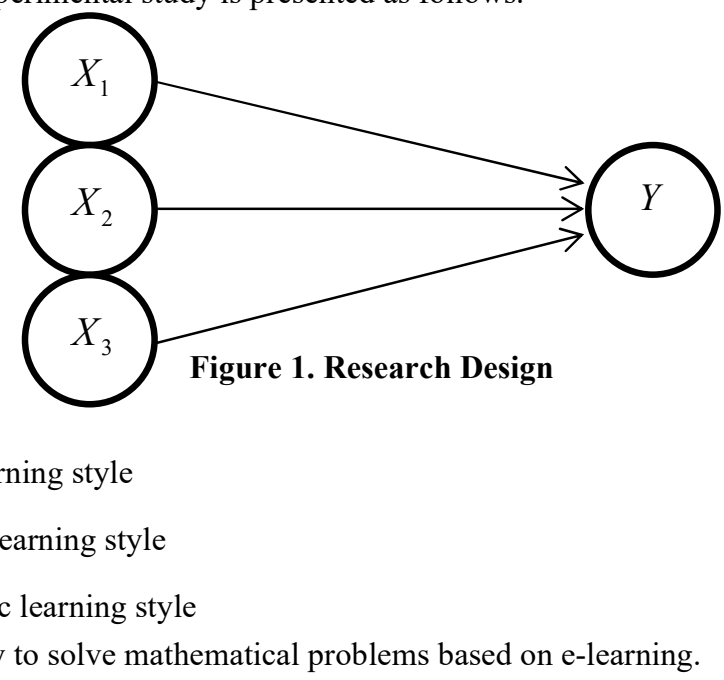

\section{Research Instruments}

\section{Learning Style Questionnaire}

To determine the learning style students have using a questionnaire. The questionnaire is a closed questionnaire in the Likert scale model. How to use a questionnaire is to give some statements to the questionnaire that already represents the three learning styles and students choose according to their personality.

\section{Mathematical Problem Solving Ability Test}

This test is conducted to determine the improvement of students' mathematical problem solving abilities. This test was arranged in the form of a description consisting of 4 questions. The scoring in measuring understanding uses a free scale, depending on the weight of the item. As said by Arikunto (2012) that in determining the highest score of the free description test using a non-fixed scale, the highest number used is not always the same. So scoring depends on the difficulty of the questions on the problem.

To determine the level of problem solving ability of students obtained from the test of students' problem solving abilities by looking at the results of student tests formed with a range of grades (0-100). In conducting an assessment of a problem solving ability test, generally it follows the assessment rules presented by Purwanto (2009), as follows.

$$
\text { score }=\frac{\text { wore value abtained }}{\text { sore maximum }} \times 100
$$

To determine the category of students' problem solving abilities, the average problem solving ability of 
students is converted to a qualitative form by paying attention to the assessment guidelines according to Arikunto (2012). After the value of students 'problem solving abilities is converted into qualitative form, it is obtained an overview of the level of students' problem solving abilities in learning mathematics.

\section{Data Analysis Technique}

\section{Significance Test (Significance) Regression Equation}

1. Determine the significance test

The steps to test the significance of using SPSS are as follows. (Riadi, 2016)

a. Click the Analyze $\rightarrow$ Regression $\rightarrow$ Linear menu.

b. Fill the Dependent box with variables $Y$ and Independent boxes with variables $X_{1}, X_{2}, X_{3}$, then click ok (the results will appear from the output data).

2. Make decision

- If the Sig. $\leq 0.05$ then it is rejected, meaning the coefficient of regression equation is significant ${ }^{H_{0}}$

- If the Sig. $>0.05$, it is accepted, meaning that the regression equation coefficient is not significant ${ }_{0}$

\section{Linearity Regression Test}

1. Determine the significance test

The steps to test the significance of using SPSS are as follows. (Riadi, 2016)

a. Click the Analyze menu $\rightarrow$ Compare Means $\rightarrow$ Means.

b. Fill the Dependent List box with variables $Y$ and the Independent List box with variables $X_{1}, X_{2}, X_{3}$, then clicking Options.

c. Choose Test for linearity, then click Continue and click ok (the results will appear from the output data).

2. Make decision

- If the Sig. $\leq 0.05$ then it is rejected, meaning that the regression line is not linear ${ }_{0}$

- If the Sig. $>0.05$, it is accepted, meaning linear regression line ${ }{ }_{0}$

\section{Estimation ModelMultiple Linear Regression Test}

Before a linear regression calculation is performed, there are several steps that must be performed according to Siregar (2014: 443), namely as follows.

1. Determine the statistical model

The multiple linear regression statistical model of this study is as follows.

$\hat{Y}=b_{0}+b_{1} X_{1}+b_{2} X_{2}+b_{3} X_{3}$

Information :

$\hat{Y} \quad$ : ability solution to problem mathematical student e-based learning

$X_{1}$ : Visual learning style

$X_{2}$ : Auditory learning style

$X_{3}$ : Kinesthetic learning style

$b_{0}$ : bound variable value

$b_{1}$ : regression coefficient between independent variables ${ }_{1}$ with respect to the dependent variable

$b_{2}$ : regression coefficient between independent variables $X_{2}$ with respect to the dependent variable

$b_{3}$ : regression coefficient between independent variables $X_{3}$ with respect to the dependent variable

2. Determine the real level

At this stage will determine how much the opportunity to make the risk of error in making decisions reject the correct hypothesis. The real level or often called the significant level is symbolized by $\alpha$. In the education sector the significance level used is $5 \%(\alpha=0,05)$. 
3. Testing rules

- Determine $F_{\text {hitung }}$

$F_{\text {hitung }}=\frac{R^{2}(n-m-1)}{m\left(1-R^{2}\right)}$

Where :

$R=\sqrt{\frac{b_{1} \sum x_{1} y+b_{2} \sum x_{2} y+b_{3} \sum x_{3} y}{\sum y^{2}}}$

- Determine $F_{\text {tnbsl }}$

df numerator (horizontal)

$=m$

df denominator (vertical)

$=n-m-1$

Information :

$m$ : many free variables

4. Make decision

$n$ : a lot of data / students

- If it is accepted, it means that there is no influence $F_{\text {hitung }} \leq F_{\text {tabel }} H_{0}$ VAK learning style (Visual, auditory, kinesthetic) towards ability solution to problem mathematical student based elearning

- If it is rejected, it means that there is influence $F_{\text {hitung }}>F_{\text {tabal }} H_{0}$ VAK learning style (Visual, auditory, kinesthetic) towards ability solution to problem mathematical student based e-learning

\section{RESULTS AND DISCUSSION}

Significance Test (Significance) Regression Equation

Table 1. Test Results The Significance of Regression Equations AgainstStudent Mathematical Problem

\section{Solving Ability Test}

Correlations

\begin{tabular}{|c|c|c|c|c|c|c|}
\hline \multicolumn{3}{|c|}{ Control Variables } & Visual & Auditory & Kinesthetic & TKPM \\
\hline \multirow[t]{12}{*}{-none-a } & \multirow[t]{3}{*}{ Visual } & Correlation & 1,000 &, 353 &, 426 & 285 \\
\hline & & Significance (2-tailed) & 2 &, 000 &, 000 & 005 \\
\hline & & Df & 0 & 94 & 94 & 94 \\
\hline & \multirow[t]{3}{*}{ Auditory } & Correlation &, 353 & 1,000 &, 557 & 096 \\
\hline & & Significance (2-tailed) &, 000 & . &, 000 & 351 \\
\hline & & Df & 94 & 0 & 94 & 94 \\
\hline & \multirow[t]{3}{*}{ Kinesthetic } & Correlation &, 426 &, 557 & 1,000 &, 143 \\
\hline & & Significance (2-tailed) &, 000 &, 000 & . &, 166 \\
\hline & & Df & 94 & 94 & 0 & 94 \\
\hline & \multirow[t]{3}{*}{ TKPM } & Correlation &, 285 &, 096 &, 143 & 1,000 \\
\hline & & Significance (2-tailed) &, 005 &, 351 &, 166 & \\
\hline & & $\mathrm{Df}$ & 94 & 94 & 94 & 0 \\
\hline
\end{tabular}

Based on the results of the SPSS output in Table 1. shows that the test results of the significance of the visual learning style with the test of students' mathematical problem solving abilities obtained Sig. in the amount of 0.005 . Because the value of Sig. smaller than $0.05(0.005<0.05)$, then H0 is rejected. So it can be concluded that the coefficient of the regression equation of visual learning style on students' mathematical problem solving ability test is significant. Furthermore, the significance test results between the auditory learning style and the students' mathematical problem-solving ability tests obtained Sig. amounted to 0.351 . Because the value of Sig. greater than $0.05(0.351>0.05)$, then $\mathrm{H}_{0}$ is accepted. So it can be concluded that the coefficient of the auditory learning style regression equation on the students' mathematical problem solving ability test is not significant. Then the significance test results between kinesthetic learning styles with students' mathematical problem solving ability tests obtained Sig. amounted to 0.166 . Because the value of Sig. greater than $0.05(0.166>0.05)$, then $\mathrm{HO}$ is accepted. So it can be concluded that the coefficient of the kinesthetic learning style regression equation on students' mathematical problem solving ability tests is not significant. Thus, it can be concluded that the coefficient of the regression equation between VAK learning styles and students' mathematical problem 
solving ability tests is not significant in auditory and kinesthetic learning styles, but significant in visual learning styles. So it can be concluded that the coefficient of the kinesthetic learning style regression equation on students' mathematical problem solving ability tests is not significant. Thus, it can be concluded that the coefficient of the regression equation between VAK learning styles and students' mathematical problem solving ability tests is not significant in auditory and kinesthetic learning styles, but significant in visual learning styles. So it can be concluded that the coefficient of the kinesthetic learning style regression equation on students' mathematical problem solving ability tests is not significant. Thus, it can be concluded that the coefficient of the regression equation between VAK learning styles and students' mathematical problem solving ability tests is not significant in auditory and kinesthetic learning styles, but significant in visual learning styles.

Linearity Regression Test

Table 2. Test Results Linearity of Regression Equations Between Visual Learning Styles and Against Student Mathematical Problem Solving Ability Test

ANOVA Table

\begin{tabular}{|c|c|c|c|c|c|}
\hline & & & Mean Square & $\mathrm{F}$ & Sig. \\
\hline \multirow{5}{*}{ TKPM * Visual } & \multirow[t]{3}{*}{ Between Groups } & (Combined) & 63,848 & 1,223 &, 267 \\
\hline & & Linearity & 419,315 & 8,035 &, 006 \\
\hline & & Deviation from Linearity & 41,631 &, 798 & 684 \\
\hline & Within Groups & & 52,189 & & \\
\hline & Total & & & & \\
\hline
\end{tabular}

Based on Table 2. shows that the results of the linearity test between visual learning styles with the test of students' mathematical problem solving abilities obtained Sig. amounted to 0.684. Because the value of Sig. greater than $0.05(0.684>0.05)$, then $\mathrm{H} 0$ is accepted. So it can be concluded that the linear regression line of visual learning style with the students' mathematical problem solving ability test is linear.

Table 3. Test Results Linearity of Regression Equations Between Auditory Learning Styles and Against Student Mathematical Problem Solving Ability Test

\section{ANOVA Table}

\begin{tabular}{|c|c|c|c|c|c|}
\hline \multirow{6}{*}{ TKPM * Auditory } & & & Mean square & $\mathrm{F}$ & Sig. \\
\hline & \multirow[t]{3}{*}{ Between Groups } & (Combined) & 76,227 & 1,530 &, 110 \\
\hline & & Linearity & 47,771 &, 959 &, 331 \\
\hline & & Deviation from Linearity & 78,124 & 1,568 &, 102 \\
\hline & Within Groups & & 49,830 & & \\
\hline & Total & & & & \\
\hline
\end{tabular}

Based on Table 3. shows that the results of the linearity test between auditory learning styles with tests of students' mathematical problem solving abilities obtained Sig. amounted to 0.102. Because the value of Sig. greater than $0.05(0.102>0.05)$, then $\mathrm{H} 0$ is accepted. So it can be concluded that the linear regression line of auditory learning style with the students' mathematical problem solving ability test is linear.

Table 4. Test Results Linearity of Regression Equations Between Kinesthetic Learning Styles and Against Student Mathematical Problem Solving Ability Test

ANOVA Table

\begin{tabular}{lllr|r|r} 
& & Mean Square & F & Sig. \\
\hline TKPM * Kinesthetic & Between Groups & (Combined) & 54,033 &, 994 &, 477 \\
\cline { 3 - 6 } & & Linearity & 104,925 & 1,931 &, 169 \\
\cline { 2 - 6 } & & Deviation from Linearity & 51,206 &, 942 &, 532 \\
\cline { 2 - 6 } & & 54,336 & & \\
\cline { 2 - 6 } & Within Groups & & & & \\
\cline { 2 - 6 } & & & & & \\
\end{tabular}

Based on Table 4. shows that the results of the linearity test between kinesthetic learning styles with tests of students' mathematical problem solving abilities obtained Sig. amounted to 0.532. Because the value of Sig. greater than $0.05(0.532>0.05)$, then $\mathrm{H} 0$ is accepted. So it can be concluded that the linear regression line of kinesthetic learning style with the test of students' mathematical problem solving ability is linear.

Thus, based on the three statements above, it can be concluded that the linear regression equation of VAK learning style with students' mathematical problem-solving ability tests is linear. 
Model of Multiple Linear Regression Test Estimation

Table 5. Statistical Models Multiple Linear Regression Between Learning VAK Against Style Student Mathematical Problem Solving Ability Test

\begin{tabular}{|c|c|c|c|c|c|}
\hline \multirow{3}{*}{ Model } & \multirow{2}{*}{\multicolumn{2}{|c|}{ Unstandardized Coefficients }} & \multirow{3}{*}{$\begin{array}{c}\text { Standardized Coefficients } \\
\text { Beta }\end{array}$} & \multirow[b]{3}{*}{$\mathrm{t}$} & \multirow[b]{3}{*}{ Sig. } \\
\hline & & & & & \\
\hline & $\mathrm{B}$ & Std. Error & & & \\
\hline 1 (Constant) & 63,831 & 8,239 & & 7,748 &, 000 \\
\hline Visual &, 589 &, 237 & 277 & 2,482 &, 015 \\
\hline Auditory &,- 043 &, 238 &,- 022 &,- 181 &, 857 \\
\hline Kinesthetic &, 063 &, 215 &, 037 &, 291 &, 772 \\
\hline
\end{tabular}

Based on Table 5. shows that the statistical model of multiple linear regression equations to estimate the effect of VAK learning styles on tests of mathematical problem solving abilities is as follows.

$$
\hat{Y}=63,831+0,589 X_{1}-0,043 X_{2}+0,063 X_{3}
$$

Table 6. Test Results Multiple Linear Regression Between Learning VAK Against Style Student Mathematical Problem Solving Ability Test

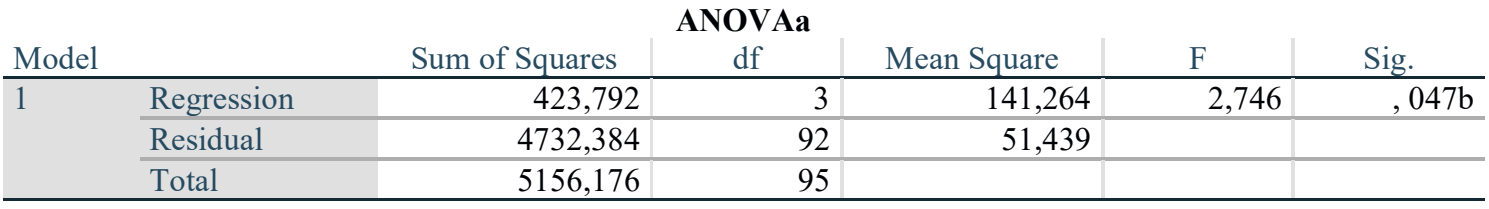

Based on Table 6 . obtained that the value of Fcount $=2.746$ and the value of $F$ table $=F\{(1-0.05)(92.3)=$ 2.70. Then it can be seen that the value of Fcount $>$ Ftable, so that the hypothesis testing rejects Ho and accepts H1. Thus it can be concluded that there is an influence of VAK learning styles (Visual, Auditory, Kinesthetic) on students' mathematical problem solving abilities.

\section{CONCLUSION}

Based on the results of the analysis, learning mathematics with VAK learning styles (Visual, Auditory, Kinesthetic) have an influence to students' mathematical problem solving abilities e-learning based. Based on the objectives, research results, and discussion as previously stated, conclusions related to learning styles, problemsolving abilities and e-learning learning were obtained, so conclusions were obtained.can influence VAK learning styles (Visual, Auditory, Kinesthetic) on students' mathematical problem solving abilities of Fcount = 2.746 greater than Table $=2.70$. In this research VAK learning styles (Visual, Auditory, Kinesthetic) are influential on students' mathematical problem solving abilities in SMP Negeri 1 Binjai, with contributionssignificant from each of them VAK learning styles (Visual, Auditory, Kinesthetic) that is as a whole by $8.2 \%$, visual learning styles by $8.1 \%$, auditory learning styles by $0.9 \%$, and kinesthetic learning styles by $2.1 \%$.

\section{BIBLIOGRAPHY}

Abdurrahman, M., (2012), Children with Learning Difficulties: Theory, Diagnosis, and Remediation, Rineka Cipta, Jakarta

Amir, A., (2013), Learning Mathematics Using Multiple Intelligences, Journal of Logarithms, 1 (1), pp.1-14

Arikunto, S., (2012), Fundamentals of Educational Evaluation, Earth Literacy, Jakarta

DePorter, B., and Hernacki, M., (2016), Quantum Learning: Familiarizing Comfortable and Enjoyable Learning, Kaifa, Bandung

DePorter, B., and Reardon, M., (2014), Quantum Learning: Practicing Quantum Learning in Classrooms, Kaifa, Bandung

Hudojo, H., (2015), Curriculum Development and Mathematics Learning, UM Press, Malang

Purwanto, (2009), Evaluation of Learning Outcomes, Student Library, Yogyakarta

Riadi, E., (2016), Research Statistics, Andi, Yogyakarta

Siregar, S., (2014), Parametric Statistics for Quantitative Research, Bumi Aksara, Jakarta

Sutikno, S., (2006), Current and Future Education, NTP Press, NTB 